\title{
PAKOM APLIKASICOOPERATIVE LEARNING UNTUK PEMBELAJARAN BAHASA INGGRIS DI SMA DAN SMK MUHAMMADIYAH SE-SURAKARTA
}

\author{
Muamaroh \\ Progdi Bahasa Inggris - FKIP \\ Universitas Muhammadiyah Surakarta \\ Jl. A. Yani Tromol Pos 1 Pabelan Kartasura Surakarta Jawa Tengah 57162 Indonesia \\ muamaroh@ums.ac.id
}

\begin{abstract}
The objective of this community serves is to give a workshop to English teachers using cooperative learning method in particular the techniques of Student Teams Achievement Division (STAD), Team-Games-Tournaments (TGT) andJigsaw STAD. This activity is also to enhance the quality of teachers in language teaching method in the class. Cooperative learning is teaching method using small group which provide students to help each other to discuss and understand lessons given by their teacher. The subject of this activity is English teachers of Muhammadiyah Senior High Schools, and Muhammadiyah Vocational schools in Surakarta. The output of this activity is participants understand and master the techniques that trained to them during the workshop. The teachers perceived that this activity is positive and very beneficial for them. They intended to implement those teaching techniques in their real English classroom.
\end{abstract}

Kata kunci: pengabdian masyarakat, pelatihan, cooperative learning, STAD, TGT, Jigsaw

\section{PENDAHULUAN}

Hingga saat ini proses pembelajaran bahasa Inggris baik ditingkat SMP/MTs maupun SMA/MA dan SMK banyak guru masih menggunakan metode pembelajaran yang tradisional. Penelitian yang dilakukan oleh White pada tahun 1997 menemukan bahwa proses belajar mengajar di Indonesia adalah teacher-centred, dengan penggunaan metode ceramah dan waktu yang hanya sedikit untuk berdiskusi di kelas. Tipe pembelajaran seperti itu masih berlangsung hingga saat ini. Hal ini senada dengan penelitian yang dilakukan oleh Martini (1996) bahwa kelemahan proses pembelajaran bahasa Inggris di Indonesia adalah tidak adanya waktu yang cukup bagi siswa untuk mempraktekkan apa yang mereka pelajari di kelas, karena guru terlalu banyak menggunakan metode ceramah atau guru menggunakan a teacher-centred approach. Dampaknya hingga saat ini siswa masih mengalami kesulitan untuk mempratekkan kemampuan dalam berkomunikasi dengan bahasa Inggris karena mereka jarang dilibatkan secara aktif dalam proses pembelajaran di kelas. Sehingga masih banyak orang yang beranggapan pembelajaran bahasa Inggris English 
Language Teaching (ELT) masih belum berhasil di Indonesia (Dardjowidjojo, 2003).

Para pengajar bahasa Inggris kebanyakan hanya terfokus pada penggunaan teksbook ketika mereka mengajar bahasa Inggris di kelas (Lie, 2007). Hal ini ditunjang oleh keberadaan bahasa Inggris sebagai satusatunya bahasa asing di Indonesia yang diujikan untuk ujian akhir nasional (UAN) untuk semua level pendidikan di tingkat SMP/MTs, maupun SMA/MA dan SMK meskipun siswa tidak mengambil jurusan bahasa Inggris mereka tetap harus mengikuti UAN bahasa Inggris (Permendiknas 46, 2010).Dengan demikian bahasa Inggris menduduki posisi yang sama pentinya dengan materi-materi wajib yang diujikan di tingkat nasional seperti bahasa Indonesia, dan matematika (Wijaya, 2008).

Di lain sisi, Guru-guru mengajar lebih memfokuskan untuk latihan soal-soal UAN terutama mereka yang mengajar kelas XII sedang untuk kelas X dan XI mereka cenderung menggunakan ceramah dengan alasan bahwa murid cenderung pasif ketika harus bekerja dalam kolompok. Alasan lain mereka menggunakan metode ceramah karena jumlah siswa yang banyak dalam satu kelas serta sarana prasarana di kelas yang tidak bisa di pindah dengan mudah. Penggunaan teknik mengajar dengan ceramah ini menjadi pilihan karena teknik ini lebih mudah untuk menyiapkannya. Guru tidak perlu untuk menyiapkan berbagai alat bantu.

Hasil temuan di lapangan menunjukkan bahwa para guru tidak banyak memiliki kesempatan untuk mengikuti pelatihan tentang metode pengajaran khususnya teknik mengajar dengan pendekatan pembelajaran kooperatifPadahal mereka dituntut untuk mengembangkan keprofesionalan mereka sebagaimana Permenpan 16 tahun 2009 tentang pengembangan keprofesian berkelanjutan. Kompetensi dan profesi guru perlu pengembangan diri dalam hal: (a) diklat fungsional, (b) kegiaan kolektif, (c) publikasi ilmiah atas hasil penelitian atau gagasan inovatif pada bidang pendidikan formal, (d) publikasi buku teks pelajaran, (e) menemukan tehnologi tepat guna, (f) menemukan/menciptakan karya seni, (g) membuat/memodifikasi alat pelajaran/ peraga/praktikum, dan (h) mengikuti pengembangan penyusunan standar, pedoman, soal dan sejenisnya.

Berdasarkan realitas di atas maka dipandang perlu untuk memberikan pelatihan kepada guru-guru pengajar bahasa Inggris dengan teknik pengajaran dengan menggunakan pendekatan cooperative learning. Tim PAKOM Pendidikan Bahasa Inggris FKIP UMS merasa perlu untuk melaksanakan kegiatan pengabdian masyarakat dengan tema "Pakom aplikasi cooperative learning untuk pembelajaran bahasa Inggris di SMA dan SMK Muhammadiyah se-Surakarta".

Berdasarkan analisis situasi di atas dan dari penjelasan mitra serta studi awal yang dilakukan tim pengabdian kepada masyarakat Pendidikan Bahasa Inggris FKIP UMS mengidentifikasi beberapa permasalahan yang dihadapi oleh para guru bahasa Inggris di sekolah menengah atas Muhammdiyah di Surakarta sebagai berikut:

1. Minimnya penguasaan guru terhadap metode pembelajaran dengan menggunakan pendekatan cooperative learning khususnya teknik Student Teams Achievement Division (STAD), TeamGames-Tournaments (TGT) dan Jigsaw sehingga mereka cenderung hanya menggunakan metode ceramah saja

2. Minimnya kompetensi profesi guru terutama yang berkaitan dengan manajemen kelas karena penggunaan metode pembelajaran kooperatif lebih menekankan pada penggunaan metode yang bertumpu pada siswa. Dimana guru dituntut untuk mampu menciptakan 
kelompok-kelompok kecil selama proses pembelajaran di kelas. Guru juga dituntut untuk tidak hanya sekedar sebagai pengajar tetapi juga sebagai fasilitator selama proses pembelajaran berlangsung di kelas.

c. Guru banyak berperan hanya sebagai pengajar atau transfer knowledge ke siswa sehingga situasi kelas cenderung pasif karena siswa lebih banyak hanya mendengarkan.

d. Minimnya kompetensi profesi guru terutama yang berkenaan dengan penguasaan keahlian berbahasa khususnya kemampuan berbicara bahasa Inggris aktif. Sehingga dampaknya guru kurang bisa menjadi role model bagi siswa dalam penggunaan bahasa Inggris. Sehingga keikutsertaan dalam pelatihan ini setidaknya akan meningkatkan kemampuan pedagogis dan profesionalitas guru.

Metode pembelajaran dengan pendekatan cooperative learning dimana pada awal tahun 1990 an lebih dari 375 penelitian yang sudah dilaksanakan dengan metode ini yang menunjukkan akan keefektifan metode ini negara maju (Garfield, 1993). Definisi cooperative learning menurut Slavin (1980, p. 315) adalah "the term [CL] refers to classroom techniques in which students work on learning activities in small groups and receive rewards and recognition based on their group's performance." Cooperative learning mengacu pada aktivitas pembelajaran dalam kelompok kecil dimana siswa mendapatkan penghargaan dan pengakuan berdasarkan performa kelompok.Kelompok kecil dalam cooperative learning bisa diri dari tiga atau empat siswa (Rimmerman, 1996 dalam Homan \& Poel, 1999, p. 4) atau kurang dari tujuh siswa (Oxford, 1997, p. 445).Semua aktivitas dalam cooperative learning menggunakan kelompok kecil dimana siswa saling menolong untuk memahami materi pelajaran (Cooper, 1990; Johnson et al., 1998, p. 28; Kluge, 1999, p. 18; Slavin, 1991, p. 71). Pendekatan ini merupakan $a$ student-centred teaching paradigm (Dörnyei, 1997, p. 491). Pendekatan ini hampir sama dengan communicative language teaching (CLT) dimana pengajaran ini merupakan student-centred. Aktifitas dalam cooperative learning sering diaplikasikan dalam communicative language teaching (Liang, 2002).

Prinsip dalam mengimplementasikan metode cooperative learning menurut Johnson et al. (1991, pp. 1-2), adalah 1.Positive interdependence: yaitu saling ketergantungan yang positif dimana semua siswa saling membutuhkan untuk menyelesaikan tugas kelompok. 2. Interaksi face-to-face dimana para siswa saling mendukung dan menyemangati dalam kelompok. 3. Individual accountability dimana setiap anggota dinilai dan berkontribusi untuk kelompok. 4. Interpersonal and small group skills dimana semua siswa dituntut untuk memiliki keterampilan untuk bersosialisasi dengan baik dalam kelompok. 5. Group processing dimana hubungan kerja sama antar anggota dalam kelompok selalu dijaga.

Dengan mengimplementasikan pembelajaran yang komunikatif maka proses pengajaran bahasa Inggris akan bisa bergeser dari pola pengajaran yang teacher-centered ke student-centered. Dimana siswa akan diberi waktu yang banyak untuk lebih bisa terlibat aktif dalam proses pembelajaran di kelas. Karena semua pembelajaran kooperatif menggunakan kelompok kecil maka hal ini mengkondisikan semua siswa bisa aktif belajar dan berdiskusi dalam kelompoknya.Sehingga guru juga bisa memantau keterlibatan semua siswa yang ada di kelas. 
Tujuan kegiatan program pengabdian masyarakat kompetetif (PAKOM) ini adalah sebagai berikut:

1. Meningkatkan penguasaan guru terhadap metode pembelajaran dengan menggunakan pendekatan cooperative learning khususnya teknik Student Teams Achievement Division (STAD), TeamGames-Tournaments (TGT) dan Jigsaw sehingga mereka bisa menerapkannya di kelas bahasa Inggris.

2. Meningkatkan kompetensi profesi guru terutama yang berkaitan dengan manajemen kelas terutama dalam pembentukan kelompok-kelompok kecil karena penggunaan metode pembelajaran kooperatif lebih menekankan pada penggunaan metode yang bertumpu pada kelompok kecil.

3. Meningkatkan peran guru tidak hanya sebagai pengajar tetapi juga fasilitator selama proses pembelajaran di kelas.

4. Meningkatkan kompetensi profesi guru terutama yang berkenaan dengan penguasaan keahlian berbahasa khususnya kemampuan berbicara bahasa Inggris aktif. Sehingga guru bisa menjadi role model bagi siswa dalam penggunaan bahasa Inggris.

Kegiatan Pakom ini memiliki kegunaan yang penting yaitu:

\section{Manfaat Umum}

Kegiatan Pakom ini diharapkan akan melahirkan kelompok guru yang konsen dengan implementasi cooperative learning di sekolah SMA dan SMK Muhammadiyah se-Surakarta. Sehingga pembelajaran bahasa Inggris di sekolah SMA dan SMK Muhammadiyah bisa bergeser dari teacher-centered menjadi student-centered.

\section{Manfaat Khusus}

a. Mengembangkan kompetensi pedagogis dari para guru dalam menguasai metode pembelajaran khususnya yang menggunakan cooperative learning dalam pembelajarn bahasa Inggris di kelas sehingga kualitas metode pengajaran guru di kelas meningkat.

b. Meningkatkan kompetensi professional guru terutama dalam menerapkan metode pembelajaran bahasa Inggris dengan pendekatan cooperative learning dimana mereka mampu mengelola kelas dengan baik dan professional. Para peserta pelatihan memahami dan bisa mengimplementasikan teknik Student Teams Achievement Division (STAD), Team-Game dan jigsaw dengan benar.

c. Adanya perubahan dan peningkatan wawasan para guru bahasa Inggris dalam mengimplementasikan metode pembelajaran dengan pendekatan cooperative learning yang memposisikan guru bukan hanya sebagai pengajar dan pentrasfer ilmu tetapi juga berperan sebagai fasilitator dalam proses pembelajaran di kelas

\section{METODE PELAKSANAAN}

Kegiatan PAKOM ini dilaksanakan dengan beberapa tahapan yaitu: Pendalaman materi untuk meningkatkan wawasan keilmuan para peserta berkenaan dengan konsep dan implementasi dari tehnik pembelajaran yang kooperatif. Kemudian pelatihan/ workshop tehnik Student Teams Achievement Division (STAD), TeamGames-Tournaments (TGT) dan Jigsaw diikuti dengan simulasi ketiga tehnik tersebut. Terakhir adalah pendampingan terhadap peserta pasca pelatihan.

Kegiatan PAKOM ini diikuti oleh delapan guru dari institusi pendidikan Muhammadiyah di Surakarta yaitu dari SMA Muhammadiyah 1, SMA Muhammadiyah 6, SMK Muhammadiyah 1, SMK Muhammadiyah 2 dan MA Mu'allimin 
Muhammadiyah. Pelatihan di laksanakan pada hari Sabtu 8 November 2014 di Balai Muhammadiyah Surakarta.Kegiatan PAKOM ini dilaksanakan selama dua bulan, yaitu sejak bulan November sampai Desember 2014.Adapun instrument yang di gunakan dalam kegiatan PAKOM ini adalah observasi, wawancara dan dokumentasi.

\section{HASIL DAN PEMBAHASAN}

Kegiatan PAKOM secara umum berhasil dengan indikator seluruh peserta mampu menguasai pembelajaran tehnik cooperative learning yaitu yang terdiri dari tehnik STAD, TGT dan jigsaw.Seluruh pesertasangat antusias ketika mengikuti pendalaman materi tentang pembelajaran yang kooperatif.Mereka sering menyampaikan pertanyaan ketika ada penjelasan yang kurang dimengerti ketika penyampaian materi.Pemateri bersama para guru yang berperan menjadi murid mempraktekkan langsung tehnik cooperative learning setelah pendalaman materi.Mereka sangat antusias ketika mengikuti simulasi tehnik Student Teams Achievement Division (STAD), Team-Games-Tournaments (TGT), dan Jigsaw.

Pendampingan dilakukan oleh Tim pengabdian UMS setelah pelatihan dengan cara mendatangi sekolah mitra dan juga melakukan pendampingan dengan menggunakan pesawat telepon mengingat beragam dan jauhnya lokasi mitra. Berdasarkan hasil pendampingan ke peserta ditemukan bahwa seluruh peserta telah menerapkan seluruh tehnik yang telah mereka dapatkan selama pelatihan kecuali satu orang guru mengatakan bahwa guru tersebut belum menerapkan tehnik kooperatif di kelasnya karena guru tersebut mengajar di kelas XII.Dimana siswa banyak dilatih untuk mengerjakan soal-soal UAN yang sebentar lagi dimulai.

Berdasarkan hasil dari pengamatan, dan wawancara secara individu keseluruh peserta maka dipandang perlu program PAKOM ini dilanjutkan dimasa yang akan datang. Hal ini didasarkan antusiasme peserta selama mengikuti pendalaman materi dan simulasi tehnik STAD, TGT dan jigsaw secara riil selama pelatihan. Alasan lain adalah antusiasme peserta untuk menerapkan ketiga tehnik yang sudah dipelajari ketika mereka mengajar bahasa Inggris di kelas.

Keberlanjutan program PAKOM ini bisa diterapkan kepada para guru yang sudah mengikuti kegiatan PAKOM ini guna meningkatkan kemampuan professional dan pedagogis mereka. Selain itu bagi para guru bahasa Inggris yang belum pernah mengikuti pelatihan pembelajaran kooperatif ini bisa dilibatkan untuk kegiatan PAKOM yang akan datang guna meningkatkan kemampuan mereka tentang pembelajaran yang kooperatif.

Pentingnya keberlanjutan kegiatan PAKOM ini diperkuat dari hasil wawancara langsung dengan semua peserta. Semua peserta menginginkan agar acara pelatihan ini dilanjutkan lagi dengan tehnik kooperatif yang lain. Kegiatan pelatihan ini sangat membantu para guru guna meningkatkan kemampuan tehnik mengajar mereka.Mereka menyatakan bahwa mereka sangat beruntung dan mendapatkan ilmu yang bermanfaat untuk metode pengajaran bahasa Inggris di kelas.

\section{SIMPULAN DAN SARAN}

\section{Simpulan}

Berdasarkan hasil dari
pengamatan, interview dan
pendampingan ke peserta kegiatan
PAKOM disimpulkan bahwa program
kegiatan PAKOM ini dinyatakan berhasil
berdasarkan indikator dari kondisi riil
peserta.Dimana peserta sudah
mendapatkan pendalaman materi dari
pemateri dan mempraktekkan secara
langsung sehingga Peserta bisa
meningkatkan kompetensi professional


mereka dengan dipahami dan dikuasainya Student Teams Achievement Division (STAD), Team-GamesTournaments (TGT), dan Jigsaw. Di lain sisi, setelah selesai workshop, Tim pengabdian masyarakat dari FKIP Bahasa Inggris juga melakukan follow up dengan melakukan pendampingan ke sekolah mitra dan via telepon untuk penerapan Cooperative Learning di sekolah mitra.

\section{Saran}

Dari delapan peserta yang mengikuti semuanya sudah menerapkan tehnik yang mereka dapatkan kecuali 1 peserta karena guru tersebut mengajar siswa kelas III. Sehingga guru tersebut lebih memfokuskan untuk mengajar siswanya dengan latihan soal-soal UAN karena di akhir kelas III mereka akan mengikuti ujian akhir nasional. Program PAKOM ini di masa yang akan datang bisa dilaksanakan dengan berbagai topik yang berbeda untuk para guru bahasa Inggris SMA dan SMK se-Surakarta. Hal ini didasarkan evaluasi dan saran dari semua peserta setelah mengikuti workshop.

\section{PERSANTUNAN}

Program pengabdian kepada masyarakat dengan judul PAKOMaplikasi cooperative learning untuk pembelajaran bahasa Inggris di SMA dan SMK Muhammadiyah se-Surakarta merupakan kerjasama antara Tim pengabdian masyarakat program studi Pendidikan bahasa Inggris dengan kepala sekolah Muhammadiyah di Surakarta yang berada di bawah koordinasi Majlis Dikdasmen PDM Surakarta.

Keberhasilan kegiatan ini tidak lepas atas bantuan dari berbagai fihak yang telah membantu hingga akhir. Untuk itu kami sampaikan rasa terima kasih kami yang tulus kepada:

1. Bapak Agus Ulinuha, Ph.D selaku ketua LPPM yang telah memberikan kepercayaan kepada kami untuk terlaksanannya kegiatan ini.

2. Profesor Dr Harun Joko Prayitno selaku Dekan FKIP UMS yang telah memberikan dukungannya selama pelaksanaan kegiatan ini

3. Bapak Dr Muhtadi selaku reviewer dari kegiatan ini yang telah banyak sekali memberikan masukan dan pengarahan kepada kami hingga terselesaikanya laporan ini.

4. Ibu Mauli Halwat Hikmat Ph.D yang telah memberikan dukungan sehingga kami bisa selesai dalam pembuatan laporan ini

5. Seluruh dosen di progdi bahasa Inggris yang telah memberikan semangat dan dukungannya dalam penyelesaian kegiatan ini.

6. Seluruh Bapak / Ibu guru Bahasa Inggris SMA/ MA/ SMK Muhammadiyah SeSurakarta yang telah hadir dalam Workshop Cooperative Learning.

\section{DAFTAR PUSTAKA}

Cooper, J. 1990. Cooperative Learning and College Instruction: Effective Use of Student Learning Teams. California: California State University Academic Publications Program. Retrieved from http://www.eric.ed.gov

Dardjowidjojo, S. 2003.English Teaching: Where and How do We Begin?In K. E. Sukamto (Ed.).Rampai Bahasa, Pendidikan, dan Budaya: Kumpulan Esai Soenjono Dardjowidjojo (pp. 29-40). Jakarta: Yayasan Obor Indonesia. 
Dörnyei, Z. 1997. Psychological Processes in Cooperative Language Learning: Group Dynamics and Motivation. The Modern Language Journal, 81(4), 482-493. Retrieved from http://tn3tv8rl4l.scholar.serialssolutions.com

Garfield, J. 1993. Teaching Statistics Using Small-group Cooperative Learning.Journal of Statistics Education, 1(1), 1-9. Retrieved from http://www.amstat.org/publications/ jse/v1n1/Garfield.html

Garfield, J. 1993. Teaching Statistics Using Small-group Cooperative Learning.Journal of Statistics Education, 1(1), 1-9. Retrieved from http://www.amstat.org/publications/ jse/v1n1/Garfield.html

Homan, R. M., \& Poel, C. J. 1999.Developing Interactive Group Skills through Cooperative Learning. Retrieved from http://www.eric.ed.gov/PDFS/ED437849.pdf

Johnson, D. W., Johnson, R. T., \& Smith, K. A. 1998. Cooperative Learning Returns to College What Evidence Is There That It Works? Change: The Magazine of Higher Learning, 30(4), 26-35. doi: 10.1080/00091389809602629.

Kluge, D. 1999. .A Brief Introduction to Cooperative Learning. Retrieved f rom http: //eric.ed.gov/ERICWeb Portal /search / detail mini.jsp?nfpb = true \& \&ERIC Ext Search SearchValue 0=ED437840\&ERIC ExtSearch SearchType 0=no\&acc $\underline{\text { no }=\text { ED437840 }}$

Komaria, O. (1998).English Language Teaching- History; English Language Teaching Indonesia.(Unpublished Master's thesis). Program Pascasarjana Universitas Katolik Indonesia Atma Jaya. Retrieved from http://lib.atmajaya.ac.id/ default.aspx $?$ tabID=61\&src=k\&id=75038.

Lauder, A. (2008). The Status and Function of English in Indonesia: A Review of Key Factors. MAKARA of Social Sciences and Humanities Series, 12(1), 9-20. Retrieved from http://journal.ui.ac.id/humanities/article/viewFile/128/124

Lie, A. (2007). Education Policy and EFL Curriculum in Indonesia: Between the Commitment to Competence and the Quest for Higher Test Scores. TEFLIN Journal, 18(1). Retrieved from http://journal.teflin.org/index.php/teflin/article/viewFile/113/102

Martani, J. Y. (1996). Directions for Reform: Perceptions of Indonesian Students towards English Language Curricula. Retrieved from http://scholarworks.umass.edu/ dissertations/AAI9709625

Oxford, R. L. (1997). Cooperative Learning, Collaborative Learning, and Interaction: Three Communicative Strands in the Language Classroom. The Modern Language Journal, 81(4), 443-456.

Permendiknas 46. (2010). Peraturan Menteri Pendidikan Nasional Republik Indonesia. Nomor 46 tahun 2010 tentang Pelaksanaan Ujian Sekolah/Madrasah dan Ujian Nasional pada Sekolah Menengah Pertama/Madrasah Tsanawiyah, Sekolah Menengah Pertama Luar Biasa, Sekolah Menengah Atas/Madrasah Aliyah, Sekolah Menengah Atas Luar Biasa, dan Sekolah Menengah Kejuruan Tahun Pelajaran 2010/2011. Retrieved from http://ww.mandikdasmen.depdiknas.go.id/web/produk/90.html. 
Simatupang, M. D. S. (1999). Bahasa Inggris Variasi Yang Mana?Suatu Tinjauan Ulang Tentang Status Bahasa Inggris Di Indonesia In B. K. Purwo (Ed.), PELBBA $12=$ Pertemuan Linguistik (Pusat Kajian) Bahasa dan Budaya Atma Jaya: Kedua Belas (pp. 63-83). Jakarta Pusat Kajian dan Budaya Unika Atma Jaya.

Slavin, R. E. (1980).Cooperative Learning.Review of Educational Research, 50(2), 315342.doi: 10.3102/00346543050002315

White, C. (1997). Indonesian Social Studies Education: A Critical Analysis. The Social Studies, 88(2), 87-92. Retrieved from http://tn3tv8rl41.scholar.serialssolutions.com

Wijaya, Henny P.S. (2008, January) .The Impacts of Changes in Education Policy on ELT in Indonesia. Paper presented at the 28th Thailand TESOL. Khon Kaen, Thailand.

Yuwono, G. (2005). English Language Teaching in Decentralised Indonesia: Voices from the Less Privileged Schools. Paper presented at AARE 2005 International Education Research Conference.Retrieved from http://www.aare.edu.au/05pap/ yuw05050.pdfKomaria, 1998). 